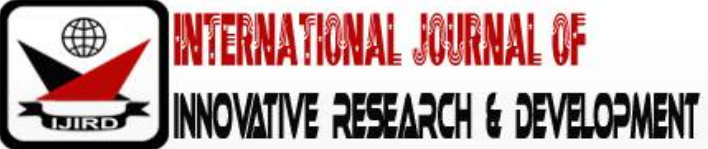

ISSN 2278 - 0211 (Online)

\section{Where Is the Foreign Direct Investment in Nigeria’s Electric Power Sector?}

\author{
Dr. George Nwangwu \\ Research Fellow, Department of Mercantile Law, Stellenbosch University, South Africa
}

\begin{abstract}
:
The main objective of the Nigerian electric power sector reform was to catalyse private sector investment in the sector. In essence, the reform involved the liberalisation and deregulation of the then wholly government owned and managed electric power sector. This was essential to augment whatever government funds were available for the upgrade of the country's collapsing electricity infrastructure. The idea was to attract majority of the investment from overseas. However, after the initial divestment of some of the government owned successor companies, it became apparent that majority of the investors in the assets were local Nigerian businesses; very few foreign investors were attracted to the nascent Nigerian electricity market. This same scenario played out again a few years later, when the government conducted the sale of additional thermal plants under the National Integrated Power Project (NIPP). On this occasion, not only did the foreign investors not show up, local investors also refused to pay for the assets. Worryingly too, there have been very few green field assets built by private sector investors since the conclusion of the electricity reforms. This paper seeks to understand the reasons for the apathy shown by foreign investors and most recently local investors to the Nigerian electricity sector. The paper suggests options for turning the situation around and encouraging the much desired private sector investment in the sector.
\end{abstract}

Keywords: Power sector, power sector reforms, foreign direct investment, Nigeria

\section{Introduction}

The major aim of the Nigerian electric power sector reform was to liberalize, deregulate and develop a competitive Nigerian electric power market from the hitherto wholly owned government monopoly. This process entailed encouraging private sector participation and investment in the sector. ${ }^{1}$ However, whilst the enactment of the Electric Power Sector Reform Act(EPSRA) has provided the legal basis for opening up of the sector to private sector ownership and management of electricity assets, it has not led to a remarkable increase in private sector investment. Consequently, the reforms have failed so far to deliver a significant improvement in power supply in the country.2

The initial divestment of the successor companies carved out of the erstwhile Power Holding Company of Nigeria ( $\mathrm{PHCN}$ ) was clearly targeted at securing investments from foreign firms. At the time, government believed that the expertise and finance required to turn around the sector resided overseas. Consequently, the government invested heavily in road shows across the world to showcase the brown field assets that were being privatised to foreign investors. ${ }^{3}$ The assets were also advertised extensively in foreign news outlets. However, after the completion of this initial wave of privatisations, it was discovered that majority of the funds used in making the acquisitions had come from local investors. Also, most of the debt was sourced from Nigerian banks. ${ }^{4}$ It appeared that foreign investors were simply not attracted to the nascent Nigerian electricity market.

A few years later, buoyed by the relative success of the first wave of asset sales, the government decided to sell off an additional ten new thermal plants, built under the National Integrated Power Project (NIPP).The NIPP project was conceived in 2005 to help increase the country's electric power generation capacity. Under this project, the government constructed 10 gas fired plants with an aggregate installed capacity of 5453MW along with complementary electricity transmission and natural gas delivery infrastructure. In 2013, the government commenced the process of privatising the

1See the Article 1 of the National Electric Power Reform Policy 2001 and S. 32 of the Electric Power Sector Reform Act, 2004.

2 According to the World Bank, the transition from publicly owned to largely owned power sector did not bring the expected outcomes. See the Power Sector Recovery Program document. Report No.124328. 
power assets through a competitive bidding process. The bid process was completed since 2014 but none of the preferred bidders paid for or took over the assets. It appears that even local investors had become sceptical of the Nigerian electricity market.

Furthermore, the liberalisation of the sector allowed private sector investors build independent power plants. All that was required of a potential investor was compliance with the requirements of the EPSRA and then the submission of an application for a generation license from the Nigerian Electricity Regulatory Commission ( NERC). ${ }^{5}$ Once a license was granted, the investor may could raise financing, construct a power plant and sell power in the electricity market.6However, despite the relaxation of the rules allowing for private sector investment in the sector, only one plant has come on stream since the enactment of the EPSRA in 2005.7It is worth noting that even this single plant was not built as a result of any consistently applied government policy to encourage investments in the sector but was due to the massive incentives offered to the investors of the project by the government. ${ }^{8}$

From the forgoing therefore, it appears that the drive to secure private sector investment in the Nigerian electric power sector has not borne any fruit. This paper evaluates why the country has not been able to attract the much needed private sector investment, whether foreign or local despite very cogent policies and laws that are aimed of achieving this. The first part of this paper is this introductory section which presents the issues that are considered in this paper. The second section examines the objectives of the Nigerian electricity reform programme. The third section takes an in depth look at the different issues bedevilling the sector and suggest ways of attracting the required investment in the sector. The final section summaries the findings and concludes the paper.

\section{The Power Sector Reform}

Prior to the commencement of the Nigerian electricity sector reform, the Nigerian power sector, had been operated by successive monopolies. These monopolies ranged from the Electricity Corporation of Nigeria (ECN) created in $1951,{ }^{9}$ the Niger Dams Authority (NDA) created in 1962 for the development of hydro-electric power, the National Electric Power Authority created in 1972 after the merger of ECN and the NDA and finally, the Power Holding Company of Nigeria (PHCN) in 2005 after the unbundling of the sector. However, throughout these successive monopolies, the country continued to experience severe shortages. For example, prior to the commencement of the electric power sector reforms, the entire country could only boast of about 1790 distribution transformers and about 680 injection substations. Also, the entire amount of electricity generated in the country was estimated to be less than 1500MW.10

The Federal Government of Nigeria, under the Obasanjo administration opted for the reform of the power sector after coming into power in 1999. The obvious reason was the dearth of electric power supply in Nigeria and its attendant negative impact on the social and economic wellbeing of the citizens and the country. According to the National Electric Power Policy, reform in the sector was necessary due to the limited access to infrastructure, low connection rate, inadequate power generation capacity, insufficient usage of capacity, lack of capital investment, ineffective regulation, high technical losses and vandalism, insufficient transmission and distribution facilities, inefficient use of electricity by consumers, inappropriate industry and market structure and unclear delineation of roles and responsibilities. ${ }^{11}$ Policy makers believed that the liberalization of the sector would help ameliorate some of these shortcomings.

The National Electric Power Reform Policy and the Electric Power Sector Reform Act (EPSRA) ushered in a new era for Nigeria's electric power sector. The major aim of the revolutionary policy instrument and legislation was to liberalize, deregulate and ultimately privatise the electric power sector by unbundling the wholly owned Federal Government Monopoly into distinct electric power business entities.According to the National Electric Power Policy:

"The objective of this policy is ultimately to establish a long term electricity market structure in Nigeria in which multiple operators provide services on a competitive basis to the broadest range of customers. Under such a regime, competitive market forces would be the best determinant of the appropriate and sustainable levels of prices charged by various carriers for their services"12

In summary, Nigeria's electric power sector reform went through three phases: The first was the legal and regulatory reform which basically opened up the electric power sector, by eliminating government's monopoly in the sector. This enabled the creation of an electric power market and provided the legal basis for private sector participation in the electric power sector.

${ }^{5} \mathrm{NERC}$ is mandated under S.32(2) (d) of the EPSRA to issue licenses to entities that wish to engage in the business of electric generation.

${ }^{6}$ There are of course other requirements required to raise financing like signing of a valid and bankable power purchase agreement.

${ }^{7}$ This is the Azura-Edo 461 MW Independent Power Plant in Edo State, Nigeria.

8 The most significant of these incentives is the World Bank back Partial Risk Guarantees that were offered the investors to backstop governments obligations under the PPA.

${ }^{9}$ See the ECN Ordinance No.15 of 1950

10National Electric Power Policy 2000 p 3.

11 See also Aderibigbe D. A. (2010) 'Power Supply to Industries- Pros and Cons of Available Options' A presentation made at the one-day conference of the Nigerian Society of Chemical Engineers, held at the Sheraton Hotel Lagos on the 7th of October, 2010. Cited in Ladan, M.T. 'Electricity Law, Policy and Reform Implementation in Nigeria 'Ahmadu Bello University Press, Kaduna Nigeria, pg. 127 Implementation Nigeria'

12 National Electric Power Policy 2000 p.33, 
The second was the institutional reforms, which led to the creation and strengthening of a number of institutions in the electricity sector. The roles of the institutions were to enable the smooth transition into a liberalised sector and also to regulate the players in the emerging electricity market. One of the institutions created was Nigerian Electricity Regulatory Commission (NERC) which acts as the technical and economic regulator for the industry. ${ }^{13}$ Also the Nigerian Bulk Electricity Trading Company (NBET) was created to carry out contract management and bulk trading of power during the transitional period ${ }^{14}$ and finally, the establishment of Nigerian Electricity Liability Management Company (NELMCO) to assume control of the stranded assets and liabilities in the power sector post-privatization. ${ }^{15}$

The third phase of the reform was the unbundling and subsequent privatization of the existing government monopoly into 18 successor companies, comprising 6-generation companies, 1 transmission company and 11 distribution companies. These successor companies, along with 10 NIPP generation assets have been subsequently privatized and the management of the PHCN successor companies handed over to the private sector investors. However the sale of the NIPP assets are yet to be completed due to a number of reasons which are discussed in this paper. ${ }^{16}$

Despite the reasonable expectations that accompanied the electricity sector reform, the country is still experiencing the electricity shortages that heralded the reforms. Notwithstanding the fact that the private sector investors have now operated the then existing PHCN assets for over 5 years, there has been only minimal improvement in generation capacities. Also, there little improvement in the volume of power distributed to citizens. Presently, only one private sector plant, the Azura IPP is in operation and the numerous potential investors who have obtained generation licenses have not built plants. The transmission grid is still largely underdeveloped and can only boast of evacuating approximately 5300MW of electricity..$^{17}$

It is the position of this paper that the root causeof this state of affairs in the Nigerian electricity sector is the lack of adequate investment in the different value chains in sector. The government has continued to invest very little in the sector, while the foreign direct investment has failed tomaterialise. It also the case that investment from the Nigerian private sector has ceased. The pertinent question which the next section of this paper tries to answer is why there has been such limited investment from the private sector despite the incentives that have been offered by the government.

\section{Diagnosis of the Problem}

\subsection{High Perception of Risk}

Foreign investors had initially submitted expression of interest proposals during the early stages of the procurement process. However, when it reached the stage where they had to make concrete commitments by putting in binding bids, most of them declined. Evidence gathered from the bid conferences suggests that the withdrawal of most of the foreign investors from the process was due to the high perception of risk in the project. A number of the foreign Investors were particularly concerned about the likelihood of political risk eventuating and had requested for the World Bank backed partial risk guarantees (PRGs)before participating in the procurement process; when this was not forthcoming, nearly all of them backed out.

It is not uncommon to use risk mitigating instruments like PRGs to manage political and commercial risks in projects, particularly in a developing country like Nigeria. However, PRGs and other similar instruments create contingent liabilities and the hesitancy of the government to offer it to potential investors is understandable. Nevertheless, Nigeria is in competition with a number of countries across the world for investment and must offer competitive terms. It is on this basis that it is suggested that the Nigerian government should in these early stages of its investment drive in the sector, offer investors some of these guarantees and slowly ease them out when the market matures and investors have gained sufficient confidence.

\subsection{Lack of Cost Reflective Tariffs}

One of the cardinal principles underlining the liberalization and deregulation of the electric power sector was that the private sector investors would be allowedto recover their investments. A corollary to this was that the government would also stop funding and subsidizing the sector in its previous manner which proved unsuccessful. In other words, the generation, distribution, transmission and all other players that add value to the sector would be able to recover the cost of producing power and make adequate returns for their investment.

Tariff in the Nigerian electricity industry is regulated by the Nigerian Electricity Regulatory Commission (NERC).The EPSRA mandates NERC to ensure that prices charged by operators are fair to customers and sufficient to allow the operators finance their activities and obtain reasonable profit for efficient operations. ${ }^{18}$ In achieving these objectives,

\footnotetext{
${ }^{13}$ created under Part III of the EPSRA.

${ }^{14}$ NBET was created and granted a trading license by NERC in 2010.
}

15 NELMCO is an SPV that was incorporated under the Companies and Allied Matters Act 2004 under the directive of the National Council on Privatisation. The initial subscribers to the Memorandum and Articles of Association of the company were the BPE and the Federal Ministry of Finance Incorporated.

16 Note that the Transmission Company was initially privatized and transferred to private sector management through a management contract. However this has now reverted into government management.

${ }^{17}$ Found online at: http:/ / www.nercng.org/ index.php/ home/ nesi/ 404-transmission; last accessed on 15 th of November, 2018.

${ }^{18} \mathrm{~S} .32(\mathrm{~d})$ of the EPSRA. 
NERC has adopted a methodology for determining electricity tariff in the Nigerian Electricity Supply Industry (NESI) called the Multi Year Tariff Order (MYTO).MYTO is designed to achieve a market reflective tariff through a transparent mechanism, which adjusts tariffs periodically in relation to inflation, cost of fuel, generation capacity and even foreign exchange fluctuations amongst other variables. ${ }^{19}$

The Electric Power Sector Reform Act (EPSRA) identifies the activities that are subject to tariff regulation to include generation, trading, transmission and distribution. ${ }^{20}$ According to the EPSRA, the tariff methodology adopted by NERC should:

- Allow a licensee that operates efficiently to recover the full cost of its business activities, including a reasonable return on the capital invested in the business;

- Provide incentive for the continued improvement of the technical and economic efficiency with which the services are provided;

- Provide incentives for the continued improvement of quality of services;

- Give consumers economically efficient signals regarding the costs that their consumption imposes on the licensee's business;

- Avoid undue discrimination between consumer and consumer categories; and

- Phase out or sustainably reduce cross subsidies..$^{21}$

The MYTO itself is essentially a tariff model that seeks to ensure that operators within the Nigerian electric power sector recover their reasonable costs incurred in the delivery of electricity to the final consumers. The MYTO therefore performs two functions: Firstly, it ensures that all the players in the Nigeria Electricity Supply Industry (NESI) recover their investments and secondly, that consumers are charged fair prices for the electricity supplied to them.

The stated objectives of the MYTO are:

- Cost recovery/ financial viability- entities operating in the NESI should recover their (efficient) costs including a reasonable return of capital.

- Certainty and stability of pricing framework which encourages an efficient level of investment.

- Incentive for improving performance. It provides incentives to reduce costs, improve quality of service and encourage the efficient use of the network.

- Allocation of risk- it promote the efficient allocation of risks

- Simplicity and cost effectiveness- it is easy to understand and implement.22

The MYTO was designed to run for a period of 15 years. However, due to the fact that its regime depends on a number of macro-economic variables, it is subject to periodic reviews by NERC. Minor reviews and major reviews are conducted bi-annually and five-yearly respectively. In conducting the major reviews, NERC is mandated to conduct extensive stakeholder consultations.

MYTO provided a level of certainty and confidence to investors at the time they were bidding for the assets, however its implementation has been flawed. NERC has not been able to properly apply the methodology due mostly to political considerations. ${ }^{23}$ The government has been very wary of increasing tariffs to MYTO required levels and therefore this has led to sever liquidity issues in the electricity market. The distribution companies have not been able to collect enough revenues from their customers to settle invoices across the electricity value chain. The government has intervened through the Central Bank of Nigeria (CBN) by offering periodic subsidies but this has not been enough to keep the market afloat. ${ }^{24}$ This has greatly eroded Investors' confidence, thereby making new investors or even potential financiers wary of making any or further investments in the sector.

\subsection{Improper Management of Exchange Rate Risks}

The management of risk is essential to the success of privately financed infrastructure projects and electric power assets are no exception. The divestment of assets and even the negotiations of greenfield PPAswas characterized by improper management of project risks. The most obvious case was the manner in which the exchange rate risk was managed. Typically, transactions in the sector were conducted in United States dollars as investors were compelled to pay for their assets in dollar denominated terms. Thus, whilst the electricity tariff is paid for by consumers in Naira, the bulk tariff that is guaranteed to investors is indexed to dollars. What this means is that whenever there is an upward shift in the value of the dollar in relation to the Naira, the tariff should go up.

\footnotetext{
${ }^{19}$ See online at http:/ / www.nercng.org/ index.php/ home/ myto Last accessed on 15th of November, 2018

20 S, 76(1) EPSRA.
}

21S. 76(2) of EPSRA.

22 NERC (2012) Multi-Year Tariff Order for the Determination of the Cost of Electricity Generation for the Period of 1 st June 2012 to 31 May 2017. Nigerian Energy Regulatory Commission, pp 7-11

23 Tariffs were suddenly dropped in 2015, just before the general elections. There were suggestions that the adjustments were politically motivated. However, NERC claims that it invalidated MYTO 2.1 which had taken effect on January 1, 2015 based on complaints especially the Manufacturers Association of Nigeria.

24The first intervention was in the form of the N213bn Nigeria Electricity Market Stabilization Facility (NEMSF), which disbursement commenced in February 2015. The second intervention was the N701bn CBN Payment Assurance Guarantee, which is used to guarantee NBET's obligations to generation companies from January 2017 to December 2018. 
For a country with a very unstable exchange rate like Nigeria, the consequences of currency fluctuations have been severe. At a point when there was close to a $100 \%$ devaluation of the local currency in relation to the dollar, the government was slow to sanction any concomitant increase in tariffs leaving the private sector investors in a worse situation. There is also the problem of the country operating multiple exchange rate regimes. In effect the government transacts its business using the current rates of N305 to 1USD while the dollar is currently exchanged in the open market at an average of N360 to 1USD. ${ }^{25}$ This means that even where the bulk tariff is adjusted, the adjustment is only made to reflect the rate at which the government transacts and not the rate at which the operators actually exchange the currency in the open market. This system effectively short changes the operators.

The long term solution to the exchange rate issues in the sector is for subsequent transactions in the sector to be conducted as much as possible in local currencies. This will greatly ameliorate a number of the currency issues that are currently bedevilling the power sector in Nigeria. It is obvious that the transactions were denominated in dollars to encourage foreign investments in the sector. However, it is obvious that majority of the investors in the sector are Nigerians and therefore there is no justification for the continued denomination of these transactions in foreign currencies.

\subsection{Lack of Investment in Transmission and Gas Infrastructure}

Whilst the generation and distribution companies were transferred to private sector operators, the government retained the management of the transmission network. However, the government has not been able to make the required investment to improve transmission and this has had a negative effect on the electricity sector. The wheeling capacity of the national grid is currently lacking behind the generation capacity. Whilst the total installed generation capacity in the country is over $12,000 \mathrm{MW}$, the countries transmission capacity is around $5300 \mathrm{MW} .26$

Similarly, it is the government's responsibility to invest in the gas infrastructure that is required as fuel for majority of the generation plants in the country. The government has not been able to make the required investment and therefore gas supply is lagging behind the available generation capacities. Consequently, most of the thermal plants are either operating below installed capacities or completely not functional due to gas constraints.

There have been suggestions by the government that it would seek to attract private sector investments in these two sectors but very little progress has been made so far. One of the major constraints to achieving this, at least in relation to gas, is that gas is not properly priced in the domestic market, therefore private sector investors have been wary of investing in the gas sector.

\subsection{Breach of Contract}

There were a number of agreements entered into between the government and the private sector operators during the privatisation exercise. The most important of these agreements is the PPA. Under the PPA, the government undertook the responsibility to pay investors capacity and energy charge but have consistently failed to meet the obligation to pay capacity charge and are therefore in breach of the terms of the Agreement. The breach of contractual agreements is consistent with the behaviour of the Nigerian government across different sectors and not unique to the power sector. This pattern of behaviour is a disincentive to private sector investment in the sector.

\subsection{Provision of incentives}

As part of the process of attracting private sector investment in the sector, the government offered a number of incentives to private sector investors. Even though there was no formal policy document enumerating these incentives, a number of them can be garnered from the EPSRA and other fiscal legislations. Also, other incentive regimes have developed from the course of negotiations between the private sector parties and the government during the privatisation process. The discussions that follow below regarding a number of these incentive schemes reveal that the private investors have not fully enjoyed even though a number of them were promised investors, the private sector operators have not enjoyed them in full.

\subsection{Creation of Independent Institutions}

Like was as mentioned above, one of the important components of the Nigerian power sector reforms was the creation of institutions to help stabilize and regulate the sector. Two of these institutions were created under the EPSRA and others through policy. Two of the most important institutions that were created under the Act are the NERC and NBET. The major reason why some of these institutions were important to private sector investors was that they were designed to be independent and therefore relatively free of government interference. The investors desired a market where decisions were determined objectively and free of the burden of political considerations, however this has not been the case in practice.

The more important of these institutions was NERC. The creation and operationalization of NERC sent a clear message to investors that the sector would be superintended by an independent credible regulator. The EPSRA made copious provisions to guarantee NERC's independence to ensure that its decisions as economic regulator is not subjected to government interference. To achieve independence, the EPSRA ensures that the Commissioners and the Executive Chairman are appointed by the President and confirmed by the Senate. ${ }^{27}$ Upon confirmation, the Commissioners may not

25 This is based on November 2018 rates.

${ }^{26}$ See http:/ / www.nercng.org/ index.php/ home/ nesi/ 404-transmission ( supra)

27 S.34(1) of the EPSRA. 
be sacked by the President except for express reasons stipulated under the Act and sanctioned by a majority vote in the Senate. ${ }^{28}$ To further buttress the independence of NERC, the Act also grants the Commission financial autonomy.29 However, despite these elaborate provisions in the Act, NERC can hardly be considered as independent in practice as its decisions seem to be made subject to political considerations. Indeed, government had by unilateral action sacked previous Commissioners of NERC without following due process.

Another institution that was created pursuant to the provisions of the EPSRA is NBET. At the time of the reform It was obvious to policy makers that the distribution companies would not be viable enough to meet the demands of power trading in the nascent electricity market. The new distribution companies were commencing operations in an environment experiencing high technical and commercial losses and it was realised that it would take time before these improved. At the bidding stage - during the first phase of privatisation, investors in the distribution companies were asked to commit to significant loss reductions within a 5-year period. However, it was also accepted that prospective investors in the generation companies required some comfort that generated power would be bought and paid for promptly regardless of the situation with the distribution companies. In order to give comfort to these investors, the Nigerian Bulk Electricity trading Company (NBET) was created and licensed by NERC.30

In line with the provisions of the EPSRA, NBET was designed as a temporary institution with the mandate to purchase power and ancillary services from independent power producers and successor generation companies for purposes of resale to the distribution companies. NBET was issued a temporary license with the belief that be gradually eased out as the distribution companies reduce their technical and commercial losses and become more capable of meeting their obligations in the market.

NBET is therefore one of the major incentives for the private sector to invest in the Nigerian electricity sector. It signed Power Purchase Agreements (PPAs) with a number of private sector generation companies. Its capitalization by the government also provided comfort to investors that the institution would be able to meet whatever shortfalls arise from electricity trading in the interim and transitional market periods. However, NBET has not been able to meet its obligations to the generation companies and debts have continued to accumulate in the sector with periodic bailouts by the CBN. NBET has also not been able to take and pay for all the power generated by the companies, leaving a lot of stranded power in the system. Even though the PPAs signed by NBET and the respective distribution companies had contemplated that in this scenario that NBET would bear the cost, NBET has refused to meet this obligation.

The present situation with NBET has greatly eroded investor confidence in the sector and is one of the major reasons why investment in the Nigerian electricity sector has dried up. There is therefore an urgent need to recapitalise NBET and ensure that it meets its obligations as at when due. Plans should also be made to gradually ease out the organisation by putting in place measures that will ensure the emergence of a sustainable competitive electricity market.

\subsection{Partial Risk Guarantees}

One of the demands of investors at the beginning of the reform programme was that the government provides partial risk guarantees (PRG). This was to manage political risk as the investors perceived this to be one of the major risks facing the project. PRGs are designed to cover losses arising from the breach of host government's contractual obligations to private sector investors. In summary, they cover risks such as expropriation, breach of contracts, sovereign debt default and currency transfer or controvertibly risk. Basically, PRGs are used to upgrade the host government's credit rating and lower the financing costs of the project. However, a major disadvantage of using PRG to finance projects is that it is expensive and therefore likely to increase the cost of delivering projects. It also has limited coverage as it does not cover political violence for instance.

However, despite the assurances by the government, the PRGs were never provided to investors. Despite Notwithstanding the non-provision of PRGs, the investors completed the acquisition in 2013, probably believing that the likelihood of the political risk eventuating was slim. Nevertheless, the government has found it difficult to meet its contractual obligations to investors and this in turn has made subsequent potential investors to demand PRGs before making any other investment. In response to this request, the government initially offered the PRG to the Azura IPP but the government has found it very difficult to offer the guarantee to other investors.

\subsection{Put and Call Option Agreements}

Another risk management device that investors have demanded is the Put and Call Option Agreements (PCOA). This agreement provides potential investors the option to request the government to buy off their concession in the event that they fail to meet their obligations under the PPAs other supporting agreements. It also allows the government "call" for the concession and pay off the private sector investors in the event that the transaction becomes difficult to continue.

The reason for the use of the PCOA is that once a power plant has been built by an investor, it becomes a sunk asset. When the investment contract ends prematurely for any reason, it becomes very impracticable for the investor to leave with the plant. Therefore, rather than paying subsidies or bail outs to investors where for instance the economic balance of the investment changes materially, the government is provided with the more politically acceptable option of buying back the asset from the investors.

28 S. 38 of the EPSRA.

${ }^{29} \mathrm{~S} .42$ and S.52 of the EPSRA

30S. 68 (2) of the Electric Power Sector Reform Act 
The PCOA was not provided to all the investors. Subsequent investors have however demanded that the government provide this agreement as an incentive to proceed with the transaction.

\section{Suggestions and Conclusions}

This paper looked at two important aspects regarding private sector investments in the Nigerian electric power sector. The first is to determine why there have been limited interest from foreign investors in the sector despite the apparent government policy of targeting such investments. Secondly, and as a follow up to the first question, is why the local investors that had supported the first wave of investments in the PHCN successor companies have refused to make further investments both in acquiring the additional assets on offer or building green field plants.

The paper concludes that reason for the lack of foreign investment was the high perception of risk in the sector at the time the assets were offered for sale by government. Foreign Investors were particularly concerned about the likelihood of political risk eventuating and had requested for the World Bank backed PRGs before participating in the procurement process, when this was not forthcoming, majority of them backed out. Perhaps it is advisable for government at this early stages of its drive for private sector investment to provide these enabling guarantees and slowly ease them out when the market matures and investors have gained sufficient confidence in the market.

That the reason for the apathy of local investors towards the privatisation of the NIPP assets was that they had simply lost confidence in the ability of the government to keep its promises. During the initial asset sale of successor companies completed in 2013, the government had offered payment guarantees ranging from cost reflective tariffs to guarantees from NBET. However, the government failed to meet these obligations, leading to massive illiquidity in the sector as investors have simply not been unable to recover anticipated returns. Therefore, when the government again issued the same payment guarantees in the course of the NIPP asset privatisation, it was no longer acceptable to the investors who now demanded World Bank backed Partial Risk Guarantees (PRGs) and other assurances as a precondition to progressing with the project. The government has simply been unable to meet these demands.

There should be a coordinated response from government where it meets its obligations to investors. The present situation where cost reflective tariffs are approved by NERC and agreements are routinely breached by government is unacceptable. There is also a need for the full implementation of MYTO to ensure that investors receive agreed tariffs. This will improve the liquidity in the sector and help engender investor confidence and investment in the electricity market.

\section{References}

i. ECN Ordinance No.15 of 1950

ii. Electric Power Sector Reform Act, 2004.

iii. National Electric Power Policy 2000

iv. National Electric Power Reform Policy 2001

v. Power Sector Recovery Program document. Report No.124328 .

vi. Aderibigbe D. A. (2010) 'Power Supply to Industries- Pros and Cons of Available

vii. Options' A presentation made at the one-day conference of the Nigerian Society of Chemical Engineers, held at the Sheraton Hotel Lagos on the 7 th of October, 2010.

viii. Cited in Ladan, M.T. Electricity Law, Policy and Reform Implementation in Nigeria

ix. 'Ahmadu Bello University Press, Kaduna Nigeria, pg. 127 Implementation Nigeria'.

x. NERC (2012) Multi-Year Tariff Order for the Determination of the Cost of Electricity Generation for the Period of 1 st June 2012 to 31 May 2017. Nigerian Energy Regulatory Commission.

xi. Nigerian Electricity Regulatory Commission; Electricity Tariff in Nigerian Electricity

xii. Supply Industry http:/ / www.nercng.org/ index.php/ home/ myto Last accessed on 15th of November, 2018.

xiii. Nigerian Electricity Regulatory Commission; Transmission

xiv. http:/ / www.nercng.org/ index.php/ home/ nesi/ 404-transmission; last accessed on 15 th of November, 2018.

xv. Vanguard Newspapers ' Nigerian Banks Invested N750bn in Power Sector Since

xvi. Privatisation' (Online) https:/ / www.vanguardngr.com/ 2014/ 08/ nigerian-banks-invested-n750bn-power-sectorsince-privatisation-adeleye/ Last accessed on 15 th of November, 2018. 